\title{
Independent Learning-Independent Campus (MBKM) in Students' Perception
}

\author{
Putri Ulfa Kamalia*, Eka Hendi Andriansyah \\ Economic Education Study Program, Faculty of Economics and Business, \\ Universitas Negeri Surabaya \\ *Corresponding Author. Email: putrikamalia@unesa.ac.id
}

\begin{abstract}
This study aims to analyze students' perception of the technical,
process and evaluation learning of the Independent Learning-Independent Campus or Merdeka Belajar-Kampus Merdeka (MBKM). This study is a descriptive with a quantitative approach. The samples in this study were students of the Economic Education Study Program, Faculty of Economics and Business, Universitas Negeri Surabaya who participated in student exchanges in the Cooperative Economics course. The instrument used is in the form of a questionnaire distributed via google form. The results obtained from this study are: 1) Students' perception of technical indicators in MBKM learning are positive; they don't experience signal problems and can access MBKM learning easily; 2) Students' perception of learning process indicators in MBKM learning on average are positive; students can understand MBKM learning materials through discussions and communication between lecturers and students goes well; 3) Students' perception of evaluation indicators in MBKM learning on average are positive; students can do midterm and final exam well independently and students are satisfied with the implementation of MBKM learning so they are interested in following it again in the next semester, but students feel that MBKM learning is not optimal because it is done online.
\end{abstract}

Article History

Received: $18-08-2021$

Revised: 09-10-2021

Accepted: 22-10-2021

Published: 11-12-2021

Key Words:

MBKM Learning,

Technical, Process,

Evaluation,

Students'

Perception

How to Cite: Kamalia, P., \& Andriansyah, E. (2021). Independent Learning-Independent Campus (MBKM) in Students' Perception. Jurnal Kependidikan: Jurnal Hasil Penelitian dan Kajian Kepustakaan di Bidang Pendidikan, Pengajaran dan Pembelajaran, 7(4), 857-867. doi:https://doi.org/10.33394/jk.v7i4.4031

\section{Introduction}

Science and technology is currently developing rapidly. The times have also created many new jobs and have also killed jobs that cannot survive in the current era. This makes university graduates expected to be the spearhead of the success of the future young generation. The government has also tried to reduce the unemployment rate by looking for a common thread between education and the world of industrial work, so that university graduates will be graduates who are ready to work with competencies in the field of expertise according to the needs of the world of work (Arifin \& Muslim, 2020). This happens because at this time the link and match is not yet optimal between the achievements of graduates and the world of business and industry (Suryaman, 2020). Graduates who are industrial in nature have high competence, innovation and economic rationality (Wijiharjono, 2021). So, it takes graduates who are creative, innovative and responsive to the changing times that are very dynamic so that universities must also improve to produce superior graduates as expected.

Currently what is needed to respond the dynamic changing times is not competition but collaboration between many parties so that the Ministry of Education and Culture develops the Independent Learning-Independent Campus program or what is often called Merdeka Belajar-Kampus Merdeka (MBKM). With the MBKM program, study programs at every university in Indonesia need to make curriculum adjustments related to determining the courses that can be taken, student quotas and setting the number of credits that can be taken 
in MBKM. Through the Independent Learning-Independent Campus (MBKM) program, students have the opportunity for one semester which is equivalent to 20 (twenty) credits of studying outside the study program at the same university, and a maximum of 2 (two) semesters which is equivalent to 40 (fourty) credits in taking learning in the same study program at different universities, learning in different study programs at different universities, and/or learning outside universities (Tohir, 2020).

The purpose of the Independent Learning-Independent Campus (MBKM) program is to prepare students to have the hard and soft skills needed in the world of work because the MBKM program concept is more industrial and tends to be practical in responding to the demands of the current era (Fachrissal, 2020). In addition, the purpose of the Independent Learning-Independence Campus (MBKM) is to provide opportunities for students to choose courses that are taken according to their passion so that they will become graduates who are ready to work (Sopiansyah \& Masruroh, 2021). Based on studies that have been conducted(Shah et al., 2020) show that the implementation of independent learning is very effective for improving cognitive skills (creativity and critical thinking), metacognitive (reflecting the entire learning process) and affective (motivation to adapt).

One of the Independent Learning-Independence Campus (MBKM) programs is student exchange. By holding student exchange, each student can voluntarily give the right to gain knowledge according to the desired passion. The benchmark for the success of implementing the MBKM Policy is to make the learning process in higher education more autonomous/independent and flexible (Yusuf \& Arfiansyah, 2021). This student exchange program run flexibly and with no restraint so that it is hoped that later students will be able to improve their competencies and be ready to work.

The Universitas Negeri Surabaya as an educational unit has implemented the Independent Learning-Independent Campus (MBKM) program, namely student exchange. The student exchange program has been carried out by every study program, including the Economic Education Study Program. In the even semester of the 2020/2021 academic year, the Economic Education Study Program has given students the right to voluntarily participate in student exchange programs, one of which is for the Cooperative Economics course which can be followed by lectures at other universities. The study program curriculum is developed by adapting MBKM policies which include planning, process, assessment and evaluation of learning (Baharuddin, 2021). The total of 16 students from two classes, namely 8 students from PE 19 A class and 8 students from PE 19 B class participated in MBKM learning for the Cooperative Economics course for one semester with a capacity of 2 credits.

Through Independent Learning-Independence Campus (MBKM) learning outside of universities, students will experience a different learning climate from their original university. In addition, the purpose of student exchange in MBKM learning is to increase the spirit of national unity and to carry out the transfer of knowledge to cover educational gaps (Kemdikbud, 2020). So far, not many studies have been found that describe the implementation results of MBKM learning because this program has just been released. Thus, the purpose of this study was to analyze how students' perception on the Independent Learning-Independence Campus (MBKM) learning. As for what will be described about the technical, learning process and evaluation of the Independent Learning-Independent Campus (MBKM) learning. Thus, this study can be used as an evaluation material for the sustainability of Independent Learning-Independent Campus (MBKM) learning for related parties, namely the government, institutions and lecturers. 


\section{Research Method}

This study is a descriptive research with a quantitative approach. Descriptive research is carried out by collecting data based on the supporting factors of the research object, which are then analyzed to find out their role (Arikunto, 2010). The sample in this study were students of the Economic Education Study Program, Faculty of Economics and Business, Universitas Negeri Surabaya who participated in student exchanges in the Independent Learning-Independent Campus (MBKM) learning at other universities in the Cooperative Economics course. The students who took part in the Independent Learning-Independent Campus (MBKM) learning were 16 students. The sampling technique used is purposive sampling (samples aimed) so that the data obtained will be more representative (Sugiyono, 2013).

Data collection techniques were carried out by distributing questionnaires through Google Forms which had been tested for validity and reliability. The instrument in the form of a questionnaire consists of 30 statements with indicators, namely technical, learning process and learning evaluation (Puspaningtyas \& Dewi, 2020) in the Independent LearningIndependent Campus (MBKM) learning. Each statement in the questionnaire has a choice of Strongly Agree (SA), Agree (A), Disagree (D) and Strongly Disagree (SD).

Table 1. Components of the Questionnaire

\begin{tabular}{clll}
\hline \multicolumn{1}{c}{ Indicator } & \multicolumn{1}{c}{ Sub-Indicator } & \multicolumn{1}{c}{ Criteria } & \multicolumn{1}{c}{ Statement } \\
\hline \multirow{2}{*}{ Technical } & \multirow{2}{*}{ Technical } & Signal & 1,2 \\
& & Internet Proficiency & 3 \\
\hline \multirow{4}{*}{ Learning process } & \multirow{2}{*}{ Interaction } & Understanding & 4,5 \\
& & Independent learn & 6,7 \\
& \multirow{2}{*}{ Teaching materials } & Understanding & 8,9 \\
& \multirow{2}{*}{ Task } & Independent learn & 10,11 \\
& \multirow{2}{*}{ Midterm Exam } & Understanding & $12,13,14$ \\
& & Independent learn & $15,16,17$ \\
\hline \multirow{3}{*}{ Learning Evaluation } & Understanding & 18,19 \\
& \multirow{2}{*}{ Final Exam } & Independent learn & 20 \\
& & Understanding & 21,22 \\
& \multirow{2}{*}{ Learning outcomes } & Independent learn & 23 \\
& Continuity & Score & 24 \\
& & Interest & 25,26 \\
& & Impact & $27,28,29,30$ \\
\hline
\end{tabular}

Source: (Puspaningtyas \& Dewi, 2020)

Data analysis technique starts from data collection and then analyzed using descriptive analysis. To be clearer and more detailed, the indicator analysis is divided into sub-indicators and broken down into several criteria. The detailed division of these components can be seen in Table 1 .

\section{Results and Discussion}

MBKM learning in the even semester of the 2020/2021 academic year has been carried out by students of the Economic Education Study Program, Faculty of Economics and Business, Universitas Negeri Surabaya, one of which is in the Cooperative Economics course. The respondents taken in this study were students of the 2019 batch who had participated in MBKM learning at other campuses. The age range of the respondents was 19 to 21 years. The distribution of the questionnaire was carried out via google form after the respondent took the final exam and obtained learning outcomes, which was around May to June 2021. According to respondents, the media often used in MBKM learning were Google Meet as much as 63\%, Vi-Learning as much as $31 \%$ and Zoom 6\%. Learning for one 
semester is carried out online (on a network) due to the Covid-19 pandemic. On the technical indicators there are three statements regarding internet signals because MBKM learning is carried out online. Students' perception of technical indicators in MBKM learning are positive; namely they do not experience signal problems, the signal in the area is smooth and can access MBKM learning easily. Table 2 contains details of the results of the recapitulation of students' perception in MBKM learning for technical indicators.

Table 2. Results of Recapitulation of Students' Perception on Technical Indicators

\begin{tabular}{clcccc}
\hline Sub-Indicator & \multicolumn{1}{c}{ Statement } & SA & A & D & SD \\
\hline & $\begin{array}{l}\text { I often experience problems related to the internet } \\
\text { signal that I use when MBKM learning is being } \\
\text { carried out }\end{array}$ & $6 \%$ & $6 \%$ & $82 \%$ & $6 \%$ \\
\cline { 2 - 6 } Technical & $\begin{array}{l}\text { I am interested in participating in MBKM } \\
\text { learning because the internet signal in my area is } \\
\text { smooth }\end{array}$ & $6 \%$ & $75 \%$ & $13 \%$ & $6 \%$ \\
\hline $\begin{array}{l}\text { I understand how to access MBKM learning via } \\
\text { online }\end{array}$ & $6 \%$ & $82 \%$ & $6 \%$ & $6 \%$ \\
\hline
\end{tabular}

The MBKM learning process indicators are divided into five sub-indicators, interactions, teaching materials and assignments. Students' perception of interaction subindicators in MBKM learning are on average positive, namely students can understand MBKM learning materials through discussion because they can see the responses of lecturers easily and communication between lecturers and students goes well during MBKM learning. However, most students want MBKM learning to be carried out offline, not online. The details of the results of the recapitulation of students' perception in MBKM learning for interaction sub-indicators can be seen in Table 3.

Table 3. Results of Recapitulation of Students' Perception on Interaction SubIndicators

\begin{tabular}{cllccc}
\hline Sub-Indicator & \multicolumn{1}{c}{ Statement } & SA & A & D & SD \\
\hline \multirow{3}{*}{ Interaction } & $\begin{array}{l}\text { I can understand MBKM learning materials } \\
\text { through discussion }\end{array}$ & $31 \%$ & $50 \%$ & $13 \%$ & $6 \%$ \\
\hline & $\begin{array}{l}\text { I'm more interested in taking MBKM learning } \\
\text { offline instead of online }\end{array}$ & $13 \%$ & $50 \%$ & $31 \%$ & $6 \%$ \\
\hline $\begin{array}{l}\text { Communication between lecturers and students } \\
\text { can run well during MBKM learning }\end{array}$ & $25 \%$ & $63 \%$ & $6 \%$ & $6 \%$ \\
\hline $\begin{array}{l}\text { Discussions when MBKM learning made it } \\
\text { easier for me to see the response of the lecture }\end{array}$ & $13 \%$ & $75 \%$ & $6 \%$ & $6 \%$ \\
\hline
\end{tabular}

Teaching materials sub-indicator consists of four statements. Students' perception of the sub-indicators of teaching materials during MBKM learning are positive, that they better understand the teaching materials made by the lecturers and often read them. The details of the results of the recapitulation of students' perception in MBKM learning for teaching materials sub-indicators can be seen in Table 4.

Table 4. Results of Recapitulation of Students' Perception on Teaching Materials Sub-

\section{Indicators}

\begin{tabular}{clcccc}
\hline Sub-Indicator & \multicolumn{1}{c}{ Statement } & SA & A & D & SD \\
\hline & $\begin{array}{l}\text { When MBKM learning, I better understand the } \\
\text { teaching materials made by the lecturer }\end{array}$ & $25 \%$ & $50 \%$ & $19 \%$ & $6 \%$ \\
\cline { 2 - 5 } $\begin{array}{c}\text { Teaching } \\
\text { Materials }\end{array}$ & $\begin{array}{l}\text { When MBKM learning, I better understand teaching } \\
\text { materials taken from other sources }\end{array}$ & $6 \%$ & $50 \%$ & $38 \%$ & $6 \%$ \\
& $\begin{array}{l}\text { I often read the teaching materials given by the } \\
\text { lecturer }\end{array}$ & $13 \%$ & $68 \%$ & $13 \%$ & $6 \%$ \\
\hline $\begin{array}{l}\text { I have read the teaching materials given by the } \\
\text { lecturer but can't understand it }\end{array}$ & $6 \%$ & $19 \%$ & $69 \%$ & $6 \%$ \\
\hline
\end{tabular}


The task sub-indicator consists of five statements. Students' perception of tasks indicators in MBKM learning are positive, namely students do not experience difficulties in doing assignments because the assignments given are not many so that they can do the task optimally and independently. The details of the results of the recapitulation of students' perception in MBKM learning for task sub-indicators can be seen in Table 5.

Table 5. Results of Recapitulation of Students' Perceptions on Task Sub-Indicators

\begin{tabular}{clcccc}
\hline Sub-Indicator & \multicolumn{1}{c}{ Statement } & SA & A & D & SD \\
\hline \multirow{5}{*}{ Task } & $\begin{array}{l}\text { When MBKM learning, too many tasks } \\
\begin{array}{l}\text { Too many tasks so that I have difficulty } \\
\text { understanding the material }\end{array}\end{array}$ & $6 \%$ & $6 \%$ & $82 \%$ & $6 \%$ \\
\hline $\begin{array}{l}\text { I can understand the material well when } \\
\text { MBKM learning so that I can do my task } \\
\text { optimally }\end{array}$ & $13 \%$ & $6 \%$ & $82 \%$ & $6 \%$ \\
\hline $\begin{array}{l}\text { I do the task given when I study MBKM } \\
\text { independently }\end{array}$ & $19 \%$ & $56 \%$ & $19 \%$ & $6 \%$ \\
\hline $\begin{array}{l}\text { I asked my friend's answer then I revised } \\
\text { I learning }\end{array}$ & $6 \%$ & $13 \%$ & $62 \%$ & $19 \%$ \\
\hline
\end{tabular}

The MBKM learning evaluation indicators are divided into four sub-indicators, namely midterm exam, final exam, learning outcomes and sustainability. Students' perceptions of midterm exam sub-indicators in MBKM learning are positive, students can work on midterm exam well independently because the midterm exam questions given are in accordance with the material that has been taught when MBKM learning. The details of student recapitulation results in MBKM learning for midterm exam sub-indicators can be seen in Table 6.

Table 6. Results of Recapitulation of Students' Perception on Midterm Exam Sub-Indicators

\begin{tabular}{clcccc}
\hline Sub-Indicator & \multicolumn{1}{c}{ Statement } & SA & A & D & SD \\
\hline & $\begin{array}{l}\text { When MBKM learning, I can understand the } \\
\text { material so that I can do midterm exam well }\end{array}$ & $25 \%$ & $50 \%$ & $19 \%$ & $6 \%$ \\
\cline { 2 - 6 } Midterm Exam & $\begin{array}{l}\text { The midterm exam questions given are in } \\
\text { accordance with what has been taught when } \\
\text { MBKM learning }\end{array}$ & $25 \%$ & $56 \%$ & $13 \%$ & $6 \%$ \\
\cline { 2 - 7 } & I do midterm exam independently & $38 \%$ & $50 \%$ & $6 \%$ & $6 \%$ \\
\hline
\end{tabular}

The final exam sub-indicator consists of three statements. Students' perception of final exam sub-indicators in MBKM learning are positive, students can do final exam well independently because the final exam questions given are in accordance with the material that has been taught when MBKM learning. The details can be seen in Table 7.

Table 7. Results of Recapitulation of Students' Perception on Final Exam SubIndicators

\begin{tabular}{clcccc}
\hline Sub-Indicator & \multicolumn{1}{c}{ Statement } & SA & A & D & SD \\
\hline \multirow{3}{*}{ Final Exam } & $\begin{array}{l}\text { When MBKM learning, I can understand the } \\
\text { material so I can do final exam well }\end{array}$ & $19 \%$ & $69 \%$ & $6 \%$ & $6 \%$ \\
\cline { 2 - 6 } & $\begin{array}{l}\text { The final exam questions given are in } \\
\text { accordance with what has been taught when } \\
\text { MBKM learning }\end{array}$ & $19 \%$ & $62 \%$ & $13 \%$ & $6 \%$ \\
\cline { 2 - 6 } & I do final exam independently & $38 \%$ & $43 \%$ & $13 \%$ & $6 \%$ \\
\hline
\end{tabular}

The Learning Outcomes Sub-Indicator consists of a statement relating to the final grades obtained by students. Students' perception of the sub-indicators of learning outcomes in MBKM learning are positive, that is, students get satisfactory grades. The details of the results of the recapitulation of students' perception in MBKM learning for the sub-indicators of learning outcomes can be seen in Table 8 . 
Table 8. Results of Recapitulation of Students' Perception on Learning Outcomes SubIndicators

\begin{tabular}{clrccr}
\hline Sub-Indicator & \multicolumn{1}{c}{ Statement } & SA & A & D & SD \\
\hline $\begin{array}{c}\text { Learning } \\
\text { Outcomes }\end{array}$ & $\begin{array}{l}\text { I get satisfactory grades in the MBKM program } \\
\text { courses }\end{array}$ & $38 \%$ & $50 \%$ & $6 \%$ & $6 \%$ \\
\hline
\end{tabular}

The impact sub-indicator consists of six statements with criteria of interest and the impact after participating in MBKM learning. Students' perception of the sustainability subindicators in MBKM learning on average are positive, namely respondents are satisfied with the implementation of MBKM learning so that they are interested in following it again in the next semester. Students get more positive impacts when participating in MBKM learning, including adding relationships and improving communication skills. However, some students do not agree that the knowledge they get is more than other friends who do not take MBKM learning. The details of the results of the recapitulation of students' perception in MBKM learning for sustainability sub-indicators can be seen in Table 9.

Table 9. Results of Recapitulation of Students' Perception on Sustainability SubIndicators

\begin{tabular}{llcccc}
\hline Sub-Indicator & \multicolumn{1}{c}{ Statement } & SA & A & D & SD \\
\hline & $\begin{array}{l}\text { I am interested in taking MBKM learning again } \\
\text { in the next semester }\end{array}$ & $13 \%$ & $68 \%$ & $13 \%$ & $6 \%$ \\
\hline $\begin{array}{l}\text { I am satisfied with the implementation of the } \\
\text { MBKM learning that I follow }\end{array}$ & $13 \%$ & $75 \%$ & $6 \%$ & $6 \%$ \\
\hline $\begin{array}{l}\text { I get a lot of relationships when MBKM learning } \\
\text { Continuity }\end{array}$ & $\begin{array}{l}\text { I get more knowledge than friends who don't take } \\
\text { MBKM learning }\end{array}$ & $13 \%$ & $62 \%$ & $19 \%$ & $6 \%$ \\
\hline $\begin{array}{l}\text { I can improve my communication skills when I } \\
\text { take MBKM learning }\end{array}$ & $6 \%$ & $82 \%$ & $6 \%$ & $6 \%$ \\
\hline $\begin{array}{l}\text { I get more positive impacts than negative impacts } \\
\text { when I take MBKM learning }\end{array}$ & $19 \%$ & $68 \%$ & $6 \%$ & $6 \%$ \\
\hline
\end{tabular}

According to the results of the analysis of student answers, MBKM learning has both positive and negative impacts. The positive impact obtained when participating in MBKM learning is to increase relations, friends and lecturers from different campuses and can improve communication skills when conducting group discussions. In addition, students can add insight regarding the learning methods used in other campuses so that they are more motivated in participating in learning to improve knowledge. Then, students can train mentally and socialize with a new environment. Furthermore, as many as $63 \%$ of students answered that there had been no negative impact when they participated in MBKM learning. It's just that students feel that MBKM learning is not optimal because it is done online, for example during group discussions on assignments.

\section{Discussion}

The media that is often used in MBKM learning is using google meet. Online learning using Google Meet can be accessed easily and effectively (Nalurita, 2020). This is in line with the results of research (Firman et al., 2021) that students prefer synchronous learning through Google Meet because they can interact directly with lecturers or other students. In addition, the advantages of using Google Meet are that is flexible, can foster student activity and can provide more learning experiences (Juniartini, 2020). So based on the existing literature, it becomes a natural thing if MBKM learning which is carried out online often uses the Google Meet media because it is considered effective compared to other media. 


\section{Students' Perception of MBKM Learning on Technical Indicators}

Based on the results of the study, most students were interested in participating in MBKM learning because they did not experience signal problems. The obstacles that occur during online learning are signal problems (Anugrahana, 2020). In line with (Rigianti, 2020) in the conclusion of his research, he explains the obstacles that often occur when online learning is carried out, namely internet network problems. So that if the internet network is stable and the quota is available, it will support the success of online learning (Putria et al., 2020). In accordance with the conclusions of the research, the majority of students don't experience signal problems so that MBKM learning can run effectively and efficiently.

Based on the study results, the majority of students can understand how to access MBKM learning by online. The ability to access and ambition of students is important in maximizing the implementation of MBKM learning (Ismail, 2020). In line with (Ariani, 2018) that human resources are an important component in online learning to be successful. If human resources lack technology mastery and have difficulty accessing online learning, then the MBKM learning objectives are difficult to achieve (Puspaningtyas \& Dewi, 2020). So that when the majority of students can access MBKM learning by online, there are no technical problems to worry about.

\section{Students' Perception of MBKM Learning on Learning Process Indicators}

Based on the results of study on interaction sub-indicators, most students can understand learning materials easily through discussion because communication between lecturers and students goes well during MBKM learning. Online learning makes students more to interact because learning is student centered (Handarini \& Wulandari, 2020). However, the majority of students want MBKM learning to be carried out offline, due to the lack of maximum interaction when carried out online. This is in line with (Ningsih, 2020) that student responses are dominated by the choice of preferring learning to be done face-toface meetings in class rather than online learning because the interaction between lecturer and students is felt to be very limited, resulting in a lack of understanding of the material obtained. In accordance with the results of a study (Maqableh \& Alia, 2021) that on average students are not satisfied with online learning because they are less focused. This is in contrast to (Rusdiana \& Nugroho, 2017) that students prefer online learning because they can develop communication when discussing the material being taught. In accordance with the findings (Kemal et al., 2021) that the MBKM learning process can run smoothly even though it is carried out online.

Based on the results of study on the teaching materials sub-indicators, some students can understand the teaching materials that have been made by their lecturers, others better understand teaching materials from other sources. One of the factors supporting the success of online learning is the skill of the lecturer in preparing appropriate teaching materials (Rusdiana \& Nugroho, 2017). So that if the lecturers who support courses in MBKM learning prepare teaching materials well, it will increase students' understanding of the material.

Based on the results of study on tasks sub-indicators, the majority of students can do the tasks given by the lecturer maximally and independently because the task given when MBKM learning are not many. When the tasks given are too many, students will have learning difficulties (Utami \& Cahyono, 2020). Giving a lot of tasks is also one of the obstacles to online learning during the Covid-19 pandemic (Anugrahana, 2020). So that when the lecturer in charge of the MBKM learning course gives tasks that are not many and proportional, students will have no difficulty in doing them, either independently or in groups. 


\section{Students' Perception of MBKM Learning on Learning Evaluation Indicators}

Based on the results of study on mid term exam and final exam sub-indicators, most students can work on midterm exam and final exam well independently because midterm exam and final exam questions are in accordance with the material that has been taught during MBKM learning. Based on the results of the study on the sub-indicators of learning outcomes, most of the students got a satisfactory score in the MBKM learning. This is in line with (Anggrawan, 2019) that the achievement of online learning learning outcomes is more successful than face-to-face learning because most students have auditory and visual learning styles. Online learning can also improve student learning outcomes (Meidawati et al., 2019). Thus, when MBKM learning is carried out online, it will not reduce student learning outcomes. MBKM learning by online also supports the success of this program because it creates many opportunities, namely students can take courses freely at other universities without being bound by space and distance (Krishnapatria, 2021).

Based on the results of the study on sustainability sub-indicators, most students get more positive impacts when participating in MBKM learning, increasing relationships and improving communication skills. This is in line with (Susilawati, 2021) that with MBKM learning, students will develop hard skills and soft skills to meet the demands of the times and will prepare graduates who are ready and superior for the sake of a quality generation of the nation. When MBKM learning, students get new experiences that can improve competence in the future (Nehe, 2021). However, most of the students did not agree if it was said that the knowledge gained was more than other friends who did not participate in MBKM learning. Thus, the proportion of knowledge obtained is relatively the same as other students who do not take MBKM learning, only that the difference is that students who take MBKM learning can increase their relationships and improve their communication skills.

\section{Conclusion}

Based on the results of the study, the conclusions that can be obtained are as follows ; (1) Students' perception of technical indicators in MBKM learning are positive, which are they don't experience signal problems and can access MBKM learning easily. (2) Students' perception of learning process indicators in MBKM learning are on average positive, in which students are able to understand the MBKM learning material through discussion and communication between lecturers and students goes well. Some students better understand the teaching materials made by lecturers and some are sourced from other teaching materials. Not many tasks given so that they can do the task optimally and independently. (3) Students' perception of learning evaluation indicators in MBKM learning are on average positive, that is students can do midterm exam and final exam well independently. Students are satisfied with the implementation of MBKM learning so they are interested in following it again in the next semester. The positive impact obtained when participating in MBKM learning is to increase the relationship of friends and lecturers and can improve communication skills when conducting group discussions. Furthermore, as many as $63 \%$ of students stated that there had been no negative impact when they participated in MBKM learning. However, students feel that MBKM learning is not optimal because it is done online.

\section{Recommendation}

Suggestions that can be put forward based on the results of the study are: (1) The head of study program and academic advisory lecturers should socialize in more detail regarding access to MBKM learning to students. (2) More mature preparation is needed for the Ministry of Education and Culture, institutions, lecturers and students so that the MBKM learning 
process keep going smoothly if it is carried out by offline after the Covid-19 Pandemic. (3) For MBKM learning lecturers, they should be more creative in preparing teaching materials in order to increase the knowledge gained for students who take MBKM learning.

\section{References}

Anggrawan, A. (2019). Analisis Deskriptif Hasil Belajar Pembelajaran Tatap Muka dan Pembelajaran Online Menurut Gaya Belajar Mahasiswa. MATRIK: Jurnal Manajemen, Teknik Informatika Dan Rekayasa Komputer, 18(2), 339-346. https://doi.org/10.30812/matrik.v18i2.411

Anugrahana, A. (2020). Hambatan, Solusi dan Harapan: Pembelajaran Daring Selama Masa Pandemi Covid-19 Oleh Guru Sekolah Dasar. Scholaria: Jurnal Pendidikan Dan Kebudayaan, 10(3), 282-289. https://doi.org/10.24246/j.js.2020.v10.i3.p282-289

Ariani, D. (2018). Komponen Pengembangan e-learning. Jurnal Pembelajaran Inovatif, 1(1), $58-64$.

Arifin, S., \& Muslim, M. (2020). TANTANGAN IMPLEMENTASI KEBIJAKAN "MERDEKA BELAJAR, KAMPUS MERDEKA" PADA PERGURUAN TINGGI ISLAM SWASTA DI INDONESIA. JURNAL PENDIDIKAN ISLAM AL-ILMI, 3(1). https://doi.org/10.32529/al-ilmi.v3i1.589

Arikunto, S. (2010). Prosedur Penelitian: Suatu Pendekatan Praktik (Edisi Revisi). Rineka Cipta.

Baharuddin, M. R. (2021). Adaptasi Kurikulum Merdeka Belajar Kampus Merdeka (Fokus: Model MBKM Program Studi). Jurnal Studi Guru Dan Pembelajaran, 4(1), 195-205. https://doi.org/10.30605/JSGP.4.1.2021.591

Fachrissal, F. (2020). "Merdeka Belajar-Kampus Merdeka" Dalam Pemikiraan Ki Hadjar Dewantara dan KH Ahmad Dahlan. Seminar Nasional Seni Dan Desain .... https://proceedings.sendesunesa.net/pt/publications/333150/merdeka-belajar-kampusmerdeka-dalam-pemikiraan-ki-hadjar-dewantara-dan-kh-ahmad

Firman, F., Sari, A. P., \& Firdaus, F. (2021). Aktivitas Mahasiswa dalam Pembelajaran Daring Berbasis Konferensi Video: Refleksi Pembelajaran Menggunakan Zoom dan Google Meet. Indonesian Journal of Educational Science (IJES), 3(2), 130-137. https://doi.org/10.31605/ijes.v3i2.969

Handarini, O. I., \& Wulandari, S. S. (2020). Pembelajaran Daring Sebagai Upaya Study From Home (SFH) Selama Pandemi Covid 19. Jurnal Pendidikan Administrasi Perkantoran (JPAP), 8(3),

https://journal.unesa.ac.id/index.php/jpap/article/view/8503

Ismail, I. (2020). Ambisi dan Kemampuan Mahasiswa Jurusan Pendidikan Seni dalam Implemtasi Kampus Merdeka. Seminar Nasional Seni Dan Desain 2020. https://proceedings.sendesunesa.net/id/publications/333154/ambisi-dan-kemampuanmahasiswa-jurusan-pendidikan-seni-dalam-implemtasi-kampus-m

Juniartini, I. R. (2020). Pemanfaatan Aplikasi Google Meet Dalam Keterampilan Menyimak Dan Berbicara Untuk Pembelajaran Bahasa Pada Masa Pandemi Covid-19 1Nme. Jurnal Pendidikan Dan Pembelajaran Bahasa Indonesia, 9(2), 133-141. https://ejournal-pasca.undiksha.ac.id/index.php/jurnal_bahasa/article/view/3537

Kemal, E., Tawandorloh, K.-A., Giawa, E. S. P., Sandra, H. K., Rusdi, F. R., \& Adela, A. P. (2021). AN ANALYSIS OF INTERACTIVE LEARNING MEDIA IN THE INTERNATIONAL TRANSFER CREDIT PROGRAM. Journal of Asian Studies: Culture, Language, Art and Communications, 2(1), 48-55. https://journal.haqipub.com/index.php/jas/article/view/24 
Kemdikbud. (2020). Buku Panduan Merdeka Belajar-Kampus Merdeka (1st ed.). Direktorat Jenderal Pendidikan Tinggi Kemdikbud RI.

Krishnapatria, K. (2021). Merdeka Belajar-Kampus Merdeka (MBKM) Curriculum in English Studies Program: Challenges and Opportunities. ELT in Focus, 4(1), 12-19. https://journal.unsika.ac.id/index.php/ELTINFOCUS/article/view/5276

Maqableh, M., \& Alia, M. (2021). Evaluation online learning of undergraduate students under lockdown amidst COVID-19 Pandemic: The online learning experience and students' satisfaction. Children and Youth Services Review, 128, 106160. https://doi.org/10.1016/j.childyouth.2021.106160

Meidawati, Sobron, Bayu, \& Rani. (2019). Pengaruh Daring Learning terhadap Hasil Belajar IPA Siswa Sekolah Dasar. In Pengaruh Daring Learning terhadap Hasil Belajar IPA Siswa Sekolah Dasar. http://conference.upgris.ac.id/index.php/snse/article/view/204/136

Nalurita, S. (2020). Pemanfaatan Aplikasi Google Meet Pada Mata Kuliah Teknik Proyeksi Bisnis Semester Gasal Tahun Pelajaran 2020/2021 Di Universitas Dirgantara Marsekal ... Jurnal Ilmiah Manajemen Surya ..., 10(1). https://journal.universitassuryadarma.ac.id/index.php/jimspc/article/view/593

Nehe, B. M. (2021). Analisis Konsep Implementasi Merdeka Belajar-Kampus Merdeka dalam Menghadapi Era Revolusi Industri 4.0 di Masa Pendemik di STKIP Setia Budhi Rangkasbitung 2021. Prosiding Seminar Nasional Pendidikan Setia Budhi, 1(1), 13-19. http://jurnal.stkipsetiabudhi.ac.id/index.php/prosiding/article/view/18/9

Ningsih, S. (2020). Persepsi Mahasiswa Terhadap Pembelajaran Daring Pada Masa Pandemi Covid-19. JINOTEP (Jurnal Inovasi Dan Teknologi Pembelajaran): Kajian Dan Riset Dalam Teknologi Pembelajaran, 7(2), 124-132. https://doi.org/10.17977/um031v7i22020p124

Puspaningtyas, N. D., \& Dewi, P. S. (2020). Persepsi Peserta Didik Terhadap Pembelajaran Berbasis Daring. Jurnal Pembelajaran Matematika Inovatif (JPMI), 3(6), 703-712. https://www.journal.ikipsiliwangi.ac.id/index.php/jpmi/article/view/5683

Putria, H., Maula, L. H., \& Uswatun, D. A. (2020). Analisis Proses Pembelajaran dalam Jaringan (DARING) Masa Pandemi Covid- 19 Pada Guru Sekolah Dasar. Jurnal Basicedu, 4(4), 861-870. https://doi.org/10.31004/basicedu.v4i4.460

Rigianti, H. A. (2020). KENDALA PEMBELAJARAN DARING GURU SEKOLAH DASAR DI BANJARNEGARA. Elementary School: Jurnal Pendidikan Dan Pembelajaran Ke-SD-An, 7(2), 297-302. https://doi.org/10.31316/esjurnal.v7i2.768

Rusdiana, E., \& Nugroho, A. (2017). Respon pada Pembelajaran Daring bagi Mahasiswa Mata Kuliah Pengantar Hukum Indonesia. Integralistik, 19(2), 148-152. https://doi.org/10.15294/integralistik.v31i1.21834

Shah, U. V., Chen, W., Inguva, P., Chadha, D., \& Brechtelsbauer, C. (2020). The discovery laboratory part II: A framework for incubating independent learning. Education for Chemical Engineers, 31, 29-37. https://doi.org/10.1016/j.ece.2020.03.003

Sopiansyah, D., \& Masruroh, S. (2021). Konsep dan Implementasi Kurikulum MBKM (Merdeka Belajar Kampus Merdeka). Reslaj: Religion Education Social Laa Roiba Journal, 4(1), 34-41. https://doi.org/10.47467/RESLAJ.V4I1.458

Sugiyono. (2013). Metode Penelitian Kuantitatif Kualitatif dan R\&D. Alfabeta.

Suryaman, M. (2020). Orientasi Pengembangan Kurikulum Merdeka Belajar. Seminar Nasional Pendidikan Bahasa Dan Sastra, 1(1), 13-28. https://ejournal.unib.ac.id/index.php/semiba/article/view/13357 
Susilawati, N. (2021). Merdeka Belajar dan Kampus Merdeka Dalam Pandangan Filsafat Pendidikan Humanisme. Jurnal Sikola: Jurnal Kajian Pendidikan Dan Pembelajaran, 2(3), 203-219. https://doi.org/10.24036/sikola.v2i3.108

Tohir, M. (2020). Buku Panduan Merdeka Belajar - Kampus Merdeka. https://doi.org/10.31219/osf.io/ujmte

Utami, Y. P., \& Cahyono, D. A. D. (2020). STUDY AT HOME: ANALISIS KESULITAN BELAJAR MATEMATIKA PADA PROSES PEMBELAJARAN DARING. Jurnal Ilmiah Matematika Realistik, 1(1), 20-26. https://doi.org/10.33365/ji-mr.v1i1.252

Wijiharjono, N. (2021). Akreditasi Perguruan Tinggi dan Kebijakan Merdeka BelajarKampus Merdeka: Sebuah Pengalaman dan Harapan. SocArXiv. https://doi.org/10.31235/OSF.IO/F9SMV

Yusuf, M., \& Arfiansyah, W. (2021). Konsep "Merdeka Belajar" dalam Pandangan Filsafat Konstruktivisme. AL-MURABBI: Jurnal Studi Kependidikan Dan Keislaman, 7(2), 120-133. https://doi.org/10.53627/jam.v7i2.3996 